\title{
Limestone particle size and artificial light for laying hens in the second laying cycle ${ }^{1}$
}

\section{Alexsandro Nunes de Oliveira², Ednardo Rodrigues Freitas ${ }^{3}$, Thales Marcel Bezerra Filgueira², Carlos Eduardo Braga $\mathrm{Cruz}^{2}$, Germano Augusto Jerônimo do Nascimento ${ }^{3}$}

\author{
${ }^{1}$ Project financed by CAPES. \\ ${ }^{2}$ Programa de Pós-graduação em Zootecnia - UFC, Fortaleza/CE, Brazil. \\ ${ }^{3}$ Departamento de Zootecnia/CCA/UFC, Fortaleza/CE, Brazil.
}

\begin{abstract}
The experiment was conducted to evaluate the effects of limestone particle size and the use of artificial light for laying hens in the second laying cycle. We used 240 Hisex White laying hens at 82 weeks of age in a completely randomized design in a $5 \times 2$ factorial arrangement, resulting in 10 treatments with 4 replicates of 6 birds. The variables were the five particle sizes obtained by increasing the proportion of thick limestone $(0,25,50,75$ and $100 \%)$ compared with thin limestone and two lighting programs: with and without artificial light. Limestone particle size and light did not affect performance or egg quality. However, there were changes in bird feeding schedule throughout the day as a response to the lighting program. Bone quality, density and mineral content of the tibia were not affected by the treatments, but limestone particle size had a quadratic effect of on bone deformity and strength, obtaining maximum inclusion points with $63 \%$ and $59 \%$ of thick limestone, respectively. The use of large particles of limestone in the diet and the use of a lighting program does not influence the performance and quality of the eggs of laying hens in the second production cycle, but the use of a proportion of $63.3 \mathrm{~g}$ of average particle size $(0.60 \mathrm{~mm})$ replacing the fine limestone $(0.23 \mathrm{~mm})$ per $100 \mathrm{~g}$ of total limestone added to the diet improves bone quality in these birds.
\end{abstract}

Key Words: calcium, eggshell, lighting, nutrition, bone strength

\section{Introduction}

In the current laying poultry scenario much attention has been given to the various factors related to the eggshell quality and bone quality of laying hens at the end of their productive lives. Thus, considering the importance of calcium in eggshell formation and bone metabolism, some researchers (Jardim Filho et al., 2005a,b; Ito et al., 2006; Murata et al., 2009) have reported the importance of studies to assess the influence of calcium sources, as well as their physical and chemical characteristics, aiming at improving the quality of eggshell and skeletal system of laying hens.

The availability of calcium for poultry during the production cycle may be influenced by differences in the particle size of the mineral sources. Thus, the rationale for using a larger particle size of calcium source in the diet of laying hens is related to the increased availability of dietary calcium during the eggshell formation at night. Thus, the larger particles of limestone are retained longer in the gizzard, dissolving more slowly than the fine particles and serving as a strategic calcium reserve to be used at the time when the egg is being formed in the shell gland, reducing the calcium requirement by bones (Leeson \& Summers, 1997).

As laying hens age, there is a drop in the eggshell quality due to factors such as lower calcium retention and increased egg weight without increasing the shell weight, in addition to the common bone fragility at the end of the production cycle (Whitehead, 2004; Murata et al., 2009). Almeida Paz et al. (2009) reported that regardless of the dietary calcium level, the laying hens mobilize the minerals from bones for eggshell formation, so bone quality reduces as they grow old.

Regarding the use of artificial lighting for laying hens, Freitas et al. (2005) reported that the practice of management extends the day length, providing a suitable light regime for laying hens, which brings the benefits of opportunity to advance or delay the laying onset, influence on the production rate, improvement in eggshell quality, optimization of egg size and maximization of feed efficiency of hens.

Given the above, the present study aims at evaluating the effects of limestone particle size, the use of artificial light and the interaction between these factors on laying hens in the second laying cycle. 


\section{Material and Methods}

The experiment was conducted at the Poultry Sector of the Department of Animal Science Center of Agrarian Sciences, Universidade Federal do Ceará, in the city of Fortaleza, located in the coastal zone of the State of Ceará, Brazil, at $15.49 \mathrm{~m}$ above the sea, $3^{\circ} 43^{\prime} 02^{\prime \prime}$ South latitude and $38^{\circ} 32^{\prime} 35^{\prime \prime}$ West longitude. A total of 240 Hisex White laying hens with 82 weeks of age and at the second laying cycle were distributed in a completely randomized design, $5 \times 2$ factorial arrangement, resulting in 10 treatments with 4 replicates of 6 birds.

From a group of poultry subjected to forced molting by the fasting method according to procedures outlined in the lineage handling manual at the 70th week of age, the poultry used in the experiment were selected based on weight and production to obtain uniform experimental plots (Sakomura \& Rostagno, 2007).

The factors studied were 5 particle sizes obtained by increasing the limestone proportion of medium particle size $(0,25,50,75$ and 100\%) compared with the fine size and 2 lighting programs: with and without artificial light.

In the order that lighting programs were applied, poultry were housed in two laying sheds, under identical conditions, placed parallel at a distance of $3 \mathrm{~m}$ between them, equipped with galvanized wire cages $(0.25 \times 0.45 \times 0.40 \mathrm{~m})$, linear feeder in galvanized chamber and nipple water dispenser at a density of two birds/cage. To avoid the light influence between sheds, black plastic curtains were placed on the sides of the sheds.

The poultry subjected to artificial light a received continuous lighting program with 16 hours of (natural + artificial) light and bulbs lit in late afternoon at 5:25 p.m.

The experimental diet was formulated (Table 1) according to the nutritional recommendations proposed in the handling manual for White Hisex lineage (edition 2006) to feed poultry in the laying phase and composition of feeds according to Rostagno et al. (2005). To obtain the different grain sizes of calcium source in the diet, the fine limestone was replaced by medium grain-size limestone at $0,25,50$, 75 and $100 \%$ in the diets.

The limestone used was obtained from the same supplier, which differentiated it (fine and coarse) commercially regarding the grain size. In determining the grain size according to the methodology described by Zanotto \& Bellaver (1996), 0.60 and $0.23 \mathrm{~mm}$ were obtained as geometric mean diameter for limestone of medium and fine particle sizes, respectively.

The temperature and relative humidity inside the sheds were measured with maximum and minimum thermometer and psychrometer, respectively. Data were recorded daily and the readings were performed at 8:00 a.m. and 4:00 p.m.

The experimental period lasted 147 days, divided into 7 periods of 21 days. At the end of each period, the leftovers were taken from the feeder and weighted. Eggs were collected daily and production was recorded. All eggs from each plot were identified, weighed and analyzed once a week.

The performance variables studied were feed intake (g/bird/day), egg production (\%/bird/day), egg weight (g), egg mass (g/bird/day) and feed conversion ( $\mathrm{kg}$ feed/kg eggs). In the egg quality evaluation, the percentages (\%) of yolk, albumen and shell, Haugh unit, specific gravity $\left(\mathrm{g} / \mathrm{cm}^{3}\right)$ and shell thickness $(\mathrm{mm})$ were assessed.

Egg specific weight was determined using the procedures described by Freitas et al. (2004). For this, the weighing system is mounted on a precision scale $(0.01 \mathrm{~g})$ to obtain the egg weight in air and water. Values of egg weight in air and water were recorded to calculate the specific gravity through the equation $\mathrm{SG}=\mathrm{WA} /(\mathrm{WW} \times \mathrm{F})$, where: $\mathrm{SG}=$ specific gravity; $\mathrm{WA}=$ egg weight in air; $\mathrm{WW}=$ egg weight in water; and $\mathrm{F}=$ temperature correction factor.

To determine the Haugh Unit we used the formula: $\mathrm{HU}=100 \log \left(\mathrm{H}+7.57-1.7 \mathrm{~W}^{0.37}\right)$, where: $\mathrm{H}=$ albumen height $(\mathrm{mm})$; and $\mathrm{W}=$ egg weight $(\mathrm{g}) ; 7.57=$ correction factor for albumen height; and $1.7=$ correction factor for egg weight.

Table 1 - Experimental diet composition

\begin{tabular}{|c|c|}
\hline Ingredients & Amount $(\mathrm{g} / \mathrm{kg})$ \\
\hline Corn & 653.4 \\
\hline Soybean meal (45\%) & 232.4 \\
\hline Limestone & 91.5 \\
\hline Monodicalcium phosphate & 15.7 \\
\hline Salt & 4.0 \\
\hline Vitamin- mineral premix ${ }^{1}$ & 3.0 \\
\hline \multicolumn{2}{|l|}{ Nutritional composition calculated } \\
\hline Metabolizable energy (Mcal/kg) & 2.73 \\
\hline Crude protein & 16.00 \\
\hline Digestible methionine & 1.80 \\
\hline Digestible methionine + digestible cystine & 5.43 \\
\hline Digestible lysine & 7.21 \\
\hline Digestible threonine & 5.44 \\
\hline Digestible tryptophan & 1.70 \\
\hline Calcium & 3.90 \\
\hline Available phosphorus & 0.40 \\
\hline Sodium & 1.80 \\
\hline \multicolumn{2}{|c|}{ 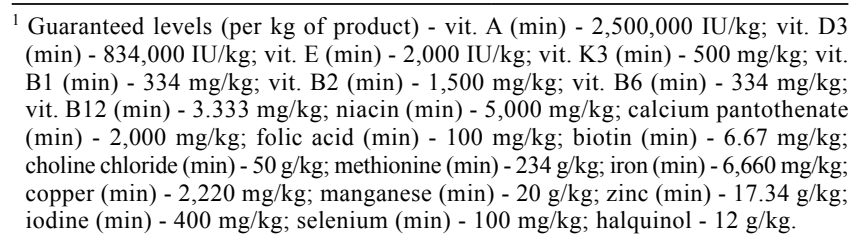 } \\
\hline
\end{tabular}


In the third experimental period we conducted an evaluation of the daily feed intake. The trial lasted a week and consumption was monitored from 6:00 a.m. to 12 p.m., 12:00 p.m. to 5:00 p.m. and 5 p.m. to 6:00 a.m. Four hundred grams of feed for each replicate of all treatments were offered at the end of each hour, and leftovers were weighed to determine intake ( $\mathrm{g} / \mathrm{bird})$.

At the end of the experiment, the poultry were weighed and then one bird per plot with similar weight to the average weight of the plot was selected. Once identified, poultry were sent to the slaughterhouse and sacrificed by cervical dislocation. After sacrifice, thighs and drumsticks were removed, properly identified and frozen at $-20{ }^{\circ} \mathrm{C}$, remaining so until the boning time.

To perform boning, pieces were removed from the freezer and placed in a domestic refrigerator at $4{ }^{\circ} \mathrm{C}$ for 12 hours for thawing and then placed on the stands so that the material reached room temperature. Subsequently, thighs and drumsticks were submerged in boiling water for 10 minutes and then boned with the aid of a scalpel according to the methodology described by Bruno (2002).

The tibiae were used for bone quality assessment. The measurement of bone length was performed using a digital caliper and the weight was obtained in an electronic scale with $0.01 \mathrm{~g}$ precision. Bone density was evaluated using the Seedor index, by dividing the weight $(\mathrm{mg})$ of the bone evaluated by its length (mm) (Seedor, 1991).

Strength parameters and bone deformity were analyzed at the Laboratory of Soil Mechanics, Department of Transportation Engineering, Universidade Federal do Ceará, using the bone (left tibia) with the aid of a Testop/ Ronald top Triaxial mechanical press with $150 \mathrm{~kg}$ capacity. Bones were placed in the horizontal position, supported at their ends on a wooden support, and then a compressive force was applied at the center of each bone. The maximum amount of force applied to the bone until its rupture was considered the breaking strength $\left(\mathrm{kgf} / \mathrm{cm}^{2}\right)$. Bone deformity $(\mathrm{mm})$ was measured by recording the flexion of each bone relative to its horizontal position until prior its rupture by the force applied using the analogical extensometer.

Bone ash was determined in the Laboratory of Animal Nutrition (LANA), Department of Animal Science, Universidade Federal do Ceará. Tibiae (right side) were weighed after boning and sent to a forced ventilation oven at $55{ }^{\circ} \mathrm{C}$ for 72 hours. They were then weighed and crushed in a ball mill. The milled samples were packed in plastic bags properly identified for subsequent determination of dry matter (DM) and mineral matter (MM) according to the methodology described by Silva \& Queiroz (2002).
The statistical analysis was performed on software SAS (Statistical Analysis System, version 9.2). Initially, data were subjected to the Shapiro-Wilk test to verify the residual normality and Levene test for homogeneity among variances. Subsequently, the analysis of variance was performed using the ANOVA module of SAS (9.2) according to a factorial model, including factors limestone particle size, light availability and the interactions between these factors. For the ingestive behavior test results, factors limestone particle size, light availability, time of evaluation and interactions between these factors were included in the model.

To evaluate the effect of changing the limestone particle size with replacement of fine by coarse limestone in the diet, regression analysis were performed, considering the different levels of limestone of medium particle size $(0,25,50,75$ and $100 \%)$. For other factors of the model, the comparison between means was performed by the SNK test at $5 \%$ probability.

\section{Results and Discussion}

There was no significant effect $(\mathrm{P}>0.05)$ of changing the particle size of the calcium source in the diet of laying hens by increasing levels of coarse limestone, use of artificial light or the interaction between these factors on feed intake, egg production, egg weight, egg mass and feed conversion (Table 2).

The results for effect of limestone particle size on poultry performance resemble those reported by other researchers (Jardim Filho et al., 2005a; Ito et al., 2006; Murata et al., 2009; Saunders-Blades et al., 2009). According to Saunders-Blades et al. (2009), the change in the particle size of calcium source does not significantly influence feed intake and consequently the performance, since even poultry subjected to different limestone particle sizes ingest enough nutrients for a good performance.

Regarding the result for light effect, it can be inferred that the lack of significant influence of extending the light period by using artificial light on performance of laying hens can be associated with the daylight length in the area where the research was carried out. During this period, the sunset and sunrise occurred at 5:25 p.m. and 5:12 a.m., respectively, totaling 12 hours and 13 minutes of natural light. Thus, while the circadian clock of birds is set to zero at the first capture of natural or artificial light after a dark period, so that the photosensitive phase occurs at about 11 hours after the initial stimulus and ends about 2 to 3 hours later (Freitas et al., 2004), the beginning of light-sensitive 
Table 2 - Performance of laying hens fed different limestone particle sizes, with or without artificial light

\begin{tabular}{|c|c|c|c|c|c|}
\hline Factors studied & Feed intake (g/bird/day) & Production (\%/bird/day) & Egg weight (g) & Egg mass (g/bird/day) & Feed conversion $(\mathrm{kg} / \mathrm{kg})$ \\
\hline \multicolumn{6}{|l|}{ Coarse limestone (\%) } \\
\hline 0 & 102.72 & 77.59 & 66.06 & 51.27 & 1.99 \\
\hline 25 & 106.83 & 77.42 & 65.47 & 50.75 & 2.14 \\
\hline 50 & 106.53 & 76.31 & 66.8 & 50.93 & 2.12 \\
\hline 75 & 107.02 & 77.94 & 65.99 & 51.42 & 2.07 \\
\hline 100 & 105.72 & 77.96 & 67.12 & 52.20 & 2.08 \\
\hline Mean & 105.76 & 77.44 & 66.29 & 51.31 & 2.08 \\
\hline \multicolumn{6}{|l|}{ Artificial light } \\
\hline With & 105.82 & 78.89 & 65.97 & 52.06 & 2.04 \\
\hline Without & 105.71 & 76.00 & 66.61 & 50.57 & 2.12 \\
\hline Mean & 105.77 & 77.45 & 66.29 & 51.32 & 2.08 \\
\hline Effects - ANOVA & & & P-value & & \\
\hline Coarse limestone & 0.176 & 0.995 & 0.606 & 0.988 & 0.690 \\
\hline Artificial light & 0.925 & 0.292 & 0.382 & 0.409 & 0.264 \\
\hline Limestone $\times$ light & 0.132 & 0.905 & 0.865 & 0.839 & 0.601 \\
\hline Regression analysis & 0.181 & 0.887 & 0.277 & 0.666 & 0.649 \\
\hline CV (\%) & 3.64 & 10.98 & 3.42 & 11.04 & 10.36 \\
\hline
\end{tabular}

ANOVA - analysis of variance; $\mathrm{CV}$ - coefficient of variation.

period in this study would start at $16 \mathrm{~h} 12$, and therefore even subjected only to natural light, birds received at least 1 hour and $13 \mathrm{~min}$ of daylight during their photosensitivity period. This amount of light was certainly enough to ensure good performance.

Another aspect to be considered is that, according to Sakomura \& Rostagno (2007), perhaps the coefficients of variation above the mean, obtained for the parameters egg production, egg mass and feed conversion, contributed to the absence of significant differences between use or nonuse of artificial light, since there was improvement in performance in favor of poultry subjected to artificial light of $2.89 \%$ in egg production, $2.94 \%$ in egg mass and $3.77 \%$ in feed conversion.

The results obtained in this study are similar to those reported by Gewehr \& Freitas (2007). According to the researchers, testing the lighting programs for laying hens in a region close to the Ecuador axis ( $3^{\circ}$ South latitude and $60^{\circ}$ west longitude), the use of approximately 12 hours of natural lighting promoted similar performance to the program using artificial light to provide 16 hours of light for laying hens, leading researchers to conclude that natural light allows keeping the production performance of whiteegg laying hens in tropical conditions.

The literature reports controversial effects for the responses of laying hens to lighting programs. Freitas et al. (2005) observed that hens subjected to increasing natural light periods (12 to 13 hours of light/day) and those subjected to a lighting program of 15 hours of constant light (natural + artificial) showed similar performance. Freitas et al. (2010), in turn, reported a reduction in egg production of laying hens reared in the same region and period of year subjected to increasing use of natural light (12 to 13 hours of light/day) compared with those subjected to a lighting program with 15 hours of constant light (natural + artificial).

Another aspect to be considered in the use of lighting programs to layers is that in some studies the light effect on poultry production has been associated with reduced feed intake promoted by programs providing few hours of light. Regarding such matters, Freitas et al. (2010) reported that the reduction in production is not always a result from changes in consumption only, since although the nutrient intake is important for sustaining high production, photostimulation is fundamental for the development of the reproductive system and to stimulate egg production.

According to the data obtained (Table 3), there was no significant effect $(\mathrm{P}>0.05)$ of the levels of coarse limestone, use of artificial light and interaction between these factors on the yolk percentage, albumen percentage, specific gravity, shell thickness, shell percentage and Haugh unit.

The results obtained for the effect of limestone particle size on egg quality are similar to those reported by other researchers (Jardim Filho et al., 2005a; Ito et al., 2006; Murata et al., 2009; Saunders-Blades et al., 2009). According to Murata et al. (2009), supplying limestone with large particle sizes may provide higher availability of calcium for eggshell formation. Saunders-Blades et al. (2009) reported that as the change in the particle size of the calcium source did not affect feed intake, poultry fed different limestone particle sizes ingest enough nutrients for egg production with good inner quality and shell quality.

Regarding the effects of the lighting program on egg quality characteristics, the results obtained in this study 
are similar to those reported by Freitas et al. (2010), who also observed no significant differences in the egg quality of laying hens subjected to increasing use of natural light (12 to 13 hours of light/day) compared with poultry subjected to a lighting program with 15 hours of constant light (natural + artificial). Gewehr \& Freitas (2007) presented several reports with absence of effects of lighting program on the egg shell quality measured by the specific weight.

In analyzing the data obtained for bone quality of laying hens (Table 4), there was no significant effect $(\mathrm{P}>0.05)$ of medium-size limestone, use of artificial light and the interaction between these factors on the bone density measured by the Seedor Index and the amount of mineral matter in the tibia. However, the deformation and cracking resistance of the tibia were significantly influenced by changing the particle size of the calcium source in the feed of laying hens by increasing the levels of medium particle size limestone.

According to regression analysis there was quadratic effect of levels of medium particle size limestone on the deformity $\left(\mathrm{Y}=2.15+0.038 \mathrm{X}-0.0003 \mathrm{X}^{2}, \mathrm{R}^{2}=0.713\right)$ and tibia breaking strength $\left(\mathrm{Y}=3.80+0.106 \mathrm{X}-0.0009 \mathrm{X}^{2}\right.$, $\left.\mathrm{R}^{2}=0.700\right)$. With the increasing proportions of limestone with medium particle size of $0.60 \mathrm{~mm}$ in the feed, there was

Table 3 - Egg quality characteristics of laying hens fed different levels of medium-particle size limestone, with or without artificial light

\begin{tabular}{|c|c|c|c|c|c|c|}
\hline Factors studied & Yolk (\%) & Albumen (\%) & Haugh Unit & Specific gravity $\left(\mathrm{g} / \mathrm{cm}^{3}\right)$ & Shell (\%) & Shell thickness (mm) \\
\hline \multicolumn{7}{|l|}{ Coarse limestone (\%) } \\
\hline 0 & 24.69 & 66.45 & 82.04 & 1.065 & 8.86 & 0.29 \\
\hline 25 & 24.32 & 66.83 & 80.69 & 1.071 & 8.85 & 0.30 \\
\hline 75 & 24.46 & 66.62 & 83.22 & 1.073 & 8.92 & 0.29 \\
\hline 100 & 24.34 & 66.60 & 81.17 & 1.073 & 9.06 & 0.31 \\
\hline Mean & 24.44 & 66.68 & 81.40 & 1.069 & 8.89 & 0.30 \\
\hline With & 24.40 & 66.70 & 81.29 & 1.069 & 8.90 & 0.30 \\
\hline Without & 24.48 & 66.65 & 81.51 & 1.068 & 8.87 & 0.29 \\
\hline Mean & 24.44 & 66.68 & 81.40 & 1.069 & 8.89 & 0.30 \\
\hline Effects - ANOVA & \multicolumn{6}{|c|}{ P-value } \\
\hline Coarse limestone & 0.884 & 0.847 & 0.082 & 0.500 & 0.467 & 0.246 \\
\hline Artificial light & 0.543 & 0.686 & 0.769 & 0.804 & 0.648 & 0.666 \\
\hline
\end{tabular}

ANOVA - analysis of variance; $\mathrm{CV}$ - coefficient of variation.

Table 4 - Characteristics of bone quality of laying hens fed different levels of medium-particle size limestone, with or without artificial light

\begin{tabular}{|c|c|c|c|c|}
\hline Factors studied & Seedor Index $(\mathrm{mg} / \mathrm{mm})$ & Deformity (mm) & Strength $\left(\mathrm{kgf} / \mathrm{cm}^{2}\right)$ & Mineral matter $(\%)$ \\
\hline \multicolumn{5}{|l|}{ Coarse limestone (\%) } \\
\hline 0 & 61.39 & 1.99 & 3.43 & 51.24 \\
\hline 25 & 61.22 & 3.17 & 6.46 & 52.82 \\
\hline 50 & 63.20 & 3.29 & 7.38 & 52.11 \\
\hline 75 & 60.19 & 2.75 & 5.47 & 52.64 \\
\hline 100 & 59.27 & 2.84 & 6.02 & 52.92 \\
\hline Mean & 61.06 & 2.81 & 5.75 & 52.35 \\
\hline \multicolumn{5}{|l|}{ Artificial light } \\
\hline With & 61.00 & 2.74 & 5.56 & 52.62 \\
\hline Without & 61.12 & 2.87 & 5.95 & 52.07 \\
\hline Mean & 61.06 & 2.81 & 5.75 & 52.35 \\
\hline Effects - ANOVA & \multicolumn{4}{|c|}{ P-value } \\
\hline Coarse limestone & 0.607 & 0.001 & 0.001 & 0.818 \\
\hline Artificial light & 0.941 & 0.493 & 0.399 & 0.583 \\
\hline Limestone $\times$ light & 0.649 & 0.549 & 0.465 & 0.276 \\
\hline Regression analysis & 0.310 & $0.001 *$ & $0.001 *$ & 0.743 \\
\hline $\mathrm{CV}(\%)$ & 8.22 & 21.85 & 24.74 & 6.03 \\
\hline
\end{tabular}

ANOVA - analysis of variance; $\mathrm{CV}$ - coefficient of variation.

* Significant quadratic effect $\left(\mathrm{Y}=2.15+0.038 \mathrm{X}-0.0003 \mathrm{X}^{2} . \mathrm{R}^{2}=0.713\right)$ and $\left(\mathrm{Y}=3.80+0.106 \mathrm{X}-0.0009 \mathrm{X}^{2} . \mathrm{R}^{2}=0.700\right)$. 
increased bone deformity, reaching the maximum estimated when the medium particle size limestone participates in the proportion of $63.3 \mathrm{~g}$ per $100 \mathrm{~g}$ of limestone added in the feed, while for bone strength the maximum was estimated when medium particle size of limestone participates in the proportion of $59 \mathrm{~g}$ per $100 \mathrm{~g}$ of limestone added to the feed.

Bone deformity measures the bone flexibility depending on the force applied on it and its value is directly related to the bone breaking strength. Thus, based on the results obtained for deformity and bone breaking strength, it can be inferred that the addition of a calcium source with particles of larger size may contribute to maintaining the bone integrity of laying hens at the end of the production cycle. Fleming et al. (1998) had greater bone strength in older laying hens (over 66 weeks) fed larger particles of limestone. However, Jardim Filho et al. (2005b) reported that the limestone particle size had no significant effect on mineral deposition and bone strength measured in the tibia of hens. Saunders-Blades et al. (2009) found that diets with larger limestone particles can reduce cases of osteoporosis and improve the poultry welfare at the end of the laying cycle.

According to Jardim Filho et al. (2005b), the different results for bone strength depending on limestone particle size found in the literature may be due to factors such as poultry age and equipment used to measure the bone strength. However, given the results obtained in the present study and those reported by some researchers (Fleming et al., 1998; Saunders-Blades et al., 2009), it can be inferred that the maintenance of bone quality in poultry seems to be the benefit obtained from changing the particle size of the calcium source in the diet, since there are frequent reports of increased resistance to breakage of bones at the end of the production cycle in poultry fed large limestone particles.

Reports in the literature regarding the lighting program effects on bone parameters of laying hens are scarce. Silversides et al. (2006) evaluated the effect of starting the photostimulation on bone quality of poultry and found that compared with later (20 weeks old), earlier (18 weeks old) application of light stimulus caused significant changes in the skeletal structure of laying hens during the production cycle, with no significant differences in the breakage resistance of bones at the end of the production cycle (74 weeks).

Moreover, we can infer that the similarity in the results obtained for bone characteristics of poultry depending on the lighting program effects is due to the absence of significant differences in feed consumption and egg production of poultry subjected to the lighting programs tested, since it has been reported that bone quality of laying hens depends upon the level of production (Silversides et al., 2006), intensity of bone resorption during the laying phase (Whitehead, 2004) and the calcium availability for eggshell formation (Fleming et al., 1998; Saunders-Blades et al., 2009).

According to the data analysis obtained for poultry ingestive behavior (Table 5), the change in limestone particle size did not affect the consumption behavior of poultry at different times of day and the total consumption during the day. This factor also showed no interaction with the others evaluated.

Regarding the light effect, the use of artificial light to supplement natural light did not affect the total consumption of poultry during the day; however, there was a significant interaction between the lighting program and

Table 5 - Effect of levels of medium particle-size limestone and artificial light on feed intake of laying hens ( $\mathrm{g} / \mathrm{bird})$ at different times

\begin{tabular}{|c|c|c|c|c|c|c|c|c|}
\hline \multirow[b]{2}{*}{ Limestone levels (\%) } & \multicolumn{4}{|c|}{ With artificial light } & \multicolumn{4}{|c|}{ Without artificial light } \\
\hline & $\begin{array}{l}\text { 6:00 a.m. to } \\
\text { 12:00 p.m. }\end{array}$ & $\begin{array}{l}\text { 12:00 p.m. to } \\
\text { 5:00 p.m. }\end{array}$ & $\begin{array}{l}\text { 5:00 p.m. to } \\
\text { 6:00 a.m. }\end{array}$ & Total & $\begin{array}{l}\text { 6:00 a.m. to } \\
12: 00 \text { p.m. }\end{array}$ & $\begin{array}{c}12: 00 \text { p.m. to } \\
\text { 5:00 p.m. }\end{array}$ & $\begin{array}{l}\text { 5:00 p.m. to } \\
\text { 6:00 a.m. }\end{array}$ & Total \\
\hline 0 & 34.43 & 26.61 & 34.06 & 95.10 & 22.39 & 32.50 & 41.07 & 95.96 \\
\hline 25 & 32.59 & 30.07 & 34.80 & 97.46 & 19.09 & 35.29 & 45.45 & 99.83 \\
\hline 50 & 35.98 & 28.98 & 34.47 & 99.43 & 27.90 & 36.50 & 42.32 & 106.72 \\
\hline 75 & 35.32 & 29.93 & 33.25 & 98.50 & 23.93 & 33.99 & 42.78 & 100.38 \\
\hline 100 & 36.94 & 32.94 & 34.34 & 104.22 & 25.84 & 33.75 & 39.18 & 98.77 \\
\hline Mean & 35.05 & 29.71 & 34.18 & 98.94 & 23.83 & 34.40 & 42.10 & 100.33 \\
\hline Effects - ANOVA & \multicolumn{8}{|c|}{$\mathrm{P}$-value } \\
\hline Limestone & \multicolumn{8}{|c|}{0.193} \\
\hline Light & \multicolumn{8}{|c|}{0.501} \\
\hline Time period & \multicolumn{8}{|c|}{0.001} \\
\hline Limestone $\times$ light & \multicolumn{8}{|c|}{0.426} \\
\hline Limestone $\times$ time & \multicolumn{8}{|c|}{0.058} \\
\hline Light $\times$ time & \multicolumn{8}{|c|}{0.001} \\
\hline Limestone $\times$ light $\times$ tim & \multicolumn{8}{|c|}{0.796} \\
\hline $\mathrm{CV}(\%)$ & \multicolumn{8}{|c|}{11.36} \\
\hline
\end{tabular}

ANOVA - analysis of variance; CV - coefficient of variation. 
time of consumption, showing that feed intake behavior did not change over the day in poultry reared with or without artificial light.

By deploying the interaction (Table 6) we observed that poultry subjected to artificial light consumed less feed between 12:00 p.m. and 5:00 p.m. and consumption was similar during the periods between 6:00 a.m. and 12:00 p.m. and between 5:00 p.m. and 6:00 a.m. However, poultry that did not receive artificial light consumed less feed from 6:00 a.m. to 12:00 p.m., increased consumption between 12:00 p.m. and 5:00 p.m. and maximized it between 5:00 p.m. and 6:00 a.m.

The change in feed intake behavior induced by time of the day on in poultry that did not receive light can be associated with an attempt of these birds to maintain nutrient intake to meet their physiological needs. Just before sunset, birds increased feed intake from 12:00 p.m. In turn, the highest consumption from 5:00 p.m. to 6:00 a.m. and the lowest between 6:00 a.m. and 12:00 p.m. may have been due to the increased feed intake shortly after dawn (5:12 a.m.). Thus, this consumption was computed along with the consumption before dusk (5:25 p.m.), increasing the values of the period from 5:00 p.m. to 6:00 a.m. Thus, this consumption was computed along with the consumption before dusk (5:25 p.m.) increasing the values of the period between 5:00 p.m. and 6:00 a.m. Moreover, when poultry were satiated with the new supply of feed between 6:00 a.m. and 12:00 p.m. feed intake decreased.

For birds subjected to artificial light at night, the reduced consumption between 12:00 p.m. and 5:00 p.m. can be associated with a strategy to reduce their metabolic heat production during hotter periods of the day, whose mean temperature was $29{ }^{\circ} \mathrm{C}$ with $73 \%$ relative humidity, since the photoperiod prolongation with artificial light enabled feed intake at periods of lower temperatures.

Although this change in consumption behavior in poultry subjected to the use of artificial light did not result in significant differences in performance and egg quality, it is noteworthy that the use of artificial light allowed for a behavioral response of animals to heat stress, providing a

Table 6 - Feed intake of laying hens (g/bird) at different times of the day according to the lighting program adopted

\begin{tabular}{llll}
\hline \multirow{2}{*}{ Period of the day } & \multicolumn{2}{c}{ Lighting program } & \multirow{2}{*}{ Mean } \\
\cline { 2 - 3 } & Without light & With light & \\
\hline 6:00 a.m. to 12:00 p.m. & $23.83 \mathrm{Cb}$ & $35.05 \mathrm{Aa}$ & 29.44 \\
12:00 p.m. to 5:00 p.m. & $34.40 \mathrm{Ba}$ & $29.71 \mathrm{Bb}$ & 32.06 \\
5:00 p.m. to 6:00 a.m. & $42.10 \mathrm{Aa}$ & $34.18 \mathrm{Ab}$ & 38.14 \\
Mean & 33.44 & 32.98 & \\
\hline
\end{tabular}

Means followed by different uppercase letters in the column and lowercase letters in the row are different by the SNK test $(\mathrm{P}<0.05)$. better welfare condition compared with those that did not undergo artificial light. Thus, this matter should be further studied especially under conditions of greater heat stress.

Changes in the feed intake behavior in poultry caused by lighting program were reported by Gewehr et al. (2005), Gewehr \& Freitas (2007) and Freitas et al. (2010). These researchers reported that the similar feed intake between laying hens exposed to lighting programs with shorter light period compared with those subjected to a longer lighting program could be attributed to an adaptation of poultry that might have offset this difference by consuming more feed during the light period to ensure a nutrient intake sufficient to meet their nutritional requirements. However, Freitas et al. (2005) reported lower feed intake in laying hens subjected to increasing use of natural light (12 to 13 hours of light/day) compared with poultry subjected to a lighting program with 15 hours of constant light (natural + artificial) .

In some regions close to the equatorial axis it is common to find egg production commercial units that do not provide artificial light to supplement the natural light and thereby subject the poultry to a photoperiod above 15 hours of light, as often recommended in the handling manual of different commercial lineages. In this context, the results obtained in this study show that the number of hours of daylight is never less than 11 hours of light throughout the year in this region; offering only natural light in the laying phase is sufficient for commercial laying hens to have similar growth performance in the second production cycle to that obtained with the use of artificial light.

Not using artificial light during the production phase reduces the cost of production due to the power energy expenses (Freitas, 2003). However, given the variations in responses of laying hens to the use of different lighting programs found in the literature and the inexistence of other studies on this practice of management in the region, further research should be conducted with a higher number of poultry to more reliably determine whether or not a prolonged light program with artificial light should be adopted in the region.

\section{Conclusions}

The use of large particles of limestone in the diet and the use of a lighting program did not influence the performance or egg quality of laying hens in the second production cycle, but the use of a proportion of $63.3 \mathrm{~g}$ of medium-particle size limestone $(0.60 \mathrm{~mm}$ diameter) replacing the fine limestone ( $0.23 \mathrm{~mm}$ diameter) per $100 \mathrm{~g}$ of total limestone added in the diet improves the bone quality of these poultry. 


\section{References}

ALMEIDA PAZ, I.C.L.; MENDES, A.A.; BALOG, A. et al. Efeito do cálcio na qualidade óssea e de ovos de poedeiras. Archivos de Zootecnia, v.58, n.222, p.173-183, 2009.

BRUNO, L.G.D. Desenvolvimento ósseo em frangos de corte: Influência da restrição alimentar e da temperatura ambiente. 2002. 72f. Tese (Doutorado em Zootecnia) - Universidade Estadual Paulista, Jaboticabal.

FLEMINIG, R.H.; McCORMACK, H.A.; WHITEHEAD, C.C. Bone structure and strength at different ages in laying hens and effects of dietary particulate limestone, vitamin $\mathrm{k}$, and ascorbic acid. British Poultry Science, v.39, p.434-440, 1998.

FREITAS, E.R.; SAKOMURA, N.K.; GONZALEZ, M.M. et al. Comparação de métodos de determinação da gravidade específica de ovos de poedeiras comerciais. Pesquisa Agropecuária Brasileira, v.39, p.509-512, 2004.

FREITAS, H.J. Avaliação de programas de iluminação para poedeiras leves e semi-pesadas. 2003. 99f. Tese (Doutorado em Zootecnia) - Universidade Federal de Lavras, Lavras.

FREITAS, H.J.; COTTA, J.T.B.; GEWEHR, C.E. Avaliação de programas de iluminação sobre o desempenho zootécnico de poedeiras leves. Ciência e Agrotecnologia, v.29, p.424-428, 2005.

FREITAS, H.J.; COTTA, J.T.B.; OLIVEIRA, A.I. et al. Efeito de diferentes programas de iluminação para poedeiras semipesadas criadas em galpões abertos. Revista Biotemas, v.23, p.157-162, 2010.

GEWEHR, C.E.; COTTA, J.T.B.; OLIVEIRA. A.I. et al. Efeitos de programas de iluminação na produção de ovos de codornas (Coturnix coturnix). Ciência e Agrotecnologia, v.29, p.857-865, 2005.

GEWEHR, C.E.; FREITAS, H.J. Iluminação intermitente para poedeiras criadas em galpões abertos. Revista de Ciências Agroveterinárias, v.6, p.54-62, 2007.

ITO, D.T.; FARIA, D.E.; KUWANO, E.A. et al. Efeitos do fracionamento do cálcio dietário e granulometria do calcário sobre o desempenho e qualidade dos ovos de poedeiras comerciais. Acta Scientiarum Animal Sciences, v.28, p.187-195, 2006.
JARDIM FILHO, R.M.; STRINGHINI, J.H.; CAFÉ, M.B. et al. Influência das fontes e granulometria do calcário calcítico sobre o desempenho e qualidade da casca dos ovos de poedeiras comerciais. Acta Scientiarum, v.27, p.35-41, 2005a.

JARDIM FILHO, R.M.; STRINGHINI, J.H.; CAFÉ, M.B. et al. Influência das fontes e granulometria do calcário calcítico sobre a densidade, resistência e composição mineral da tíbia de poedeiras comerciais. Acta Scientiarum, v.27, p.23-28, 2005b.

LEESON, S.; SUMMERS, J.D. Commercial poultry nutrition. 2.ed. Guelph: University Books, 1997. 350p.

MURATA, L.S.; ARIKI, J.; SANTANA, A.P.; et al. Níveis de cálcio e granulometria do calcário sobre o desempenho e a qualidade da casca de ovos de poedeiras comerciais. Revista Biotemas, v.22, p.103-110, 2009.

ROSTAGNO, H.S.; ALBINO, L.F.T.; DONZELE, J.L. et al. Tabelas brasileiras para aves e suínos: Composição de alimentos e exigências nutricionais. 2.ed. Viçosa, MG: UFV, 2005. 186p.

SAKOMURA, N.K.; ROSTAGNO, H.S. Métodos de pesquisa em nutrição de monogástricos. Jaboticabal: FUNEP, 2007. 283p

SAUNDERS-BLADES, J.L.; MACISAAC, J.L.; KORVER, D.R. et al. The effect of calcium source and particle size on the production performance and bone quality of laying hens. Poultry Science, v.88, p.338-353, 2009.

SEEDOR, J.G. The biophosphanate alendronate (MK-217) inhibit bone loss due to ovariectomy in rats. Bone and Mineral Research, v.6, p.339-346, 1991.

SILVA, D.J.; QUEIROZ, A.C. Análise de alimentos. In: Métodos químicos e biológicos. 3.ed. Viçosa, MG: UFV, 2002. 167p.

SILVERSIDES, F.G.; KORVER, D.R.; BUDGELL, K.L. Effect of strain of layer and age at photostimulation on egg production, egg quality, and bone strength. Poultry Science, v.85, p.1136-1144, 2006.

WHITEHEAD, C.C. Overview of bone biology in the egg-laying hen. Poultry Science, v.83, p.193-199, 2004.

ZANOTTO, D.L.; BELLAVER, C. [1996]. Métodos de determinação da granulometria de ingredientes para o uso em rações de suínos e aves. Available at: <http://www.cnpsa.embrapa.br/sgc/ sgc_publicacoes/cot215.pdf $>$ Accessed on: May 5, 2011. 